Available online at

SciVerse ScienceDirect

www.sciencedirect.com
Elsevier Masson France

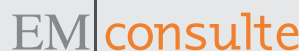

www.em-consulte.com/en

\title{
Effects of titanium dioxide nanoparticles in human gastric epithelial cells in vitro
}

\author{
Monica Catarina Botelho ${ }^{\mathrm{a}, \mathrm{b}, *}$, Carla Costa $^{\mathrm{c}}$, Susana Silva ${ }^{\mathrm{a}}$, Solange Costa ${ }^{\mathrm{a}}$, Alok Dhawan ${ }^{\mathrm{d}, \mathrm{e}}$, \\ Paula A. Oliveira ${ }^{\text {b,f }}$, João P. Teixeira ${ }^{a}$ \\ a INSA National Institute of Health, Department of Health Promotion, Porto, Portugal \\ ${ }^{\mathrm{b}}$ CECA Centre for the Study of Animal Science, ICETA, Porto University, Porto, Portugal \\ ${ }^{c}$ ISPUP Institute of Public Health-University of Porto, Porto, Portugal \\ ${ }^{\mathrm{d}}$ Nanomaterial Toxicology Group, Indian Institute of Toxicology Research, Lucknow, India \\ e Institute of Life Sciences, School of Science and Technology, Ahmedabad University, Gujarat, India \\ ${ }^{\mathrm{f}}$ UTAD Department of Pathology, University of Trás-os-Montes e Alto Douro, Vila Real, Portugal
}

\section{A R T I C L E I N F O}

\section{Article history:}

Received 24 July 2013

Accepted 10 August 2013

\section{Keywords:}

$\mathrm{TiO}_{2}$ nanoparticles

Gastric epithelial cells

Proliferation

Apoptosis

Oxidative stress

Genotoxicity

\begin{abstract}
A B S T R A C T
Manufacturing or using nanomaterials may result in exposure of workers to nanoparticles. Potential routes of exposure include skin, lung and gastrointestinal tract. The lack of health-based standards for nanomaterials combined with their increasing use in many different workplaces and products emphasize the need for a reliable temporary risk assessment tool. Therefore, the aim of this work was to explore the effects of different doses of titanium dioxide nanoparticles on human gastric epithelial cells in vitro. We analyzed proliferation by MTT assay, apoptosis by Tunel, migration by injury assay, oxidative stress by determining GSH/GSSG ratio and DNA damage by Comet assay on nanoparticle-treated AGS human gastric epithelial cell line in comparison to controls. We show and discuss the tumor-like phenotypes of nanoparticles-exposed AGS cells in vitro, as increased proliferation and decreased apoptosis. Our results demonstrate for the first time that nanoparticles induce tumor-like phenotypes in human gastric epithelial cells.
\end{abstract}

(c) 2013 Elsevier Masson SAS. All rights reserved.

\section{Introduction}

Nanotechnology is one of the fastest growing sectors of the high-tech economy. There are more than 200 separate consumer products alone using nanomaterials with personal, commercial, medical, and military uses $[1,2]$. Engineered nanomaterials with dimension of $100 \mathrm{~nm}$ or less provide us a wide range of novel applications in the electronics, healthcare, cosmetics, technologies and engineering industries. The exploitation of properties inherent to materials at the nanoscale has initiated innovative approaches to technologies which shape our world. Lack of toxicological data on nanomaterials makes it difficult to determine if there is a risk associated with nanomaterials exposure. Thus, there is an urgent need to develop rapid, accurate and efficient testing strategies to assess health effect of these emerging materials [3].

Nano-sized or ultrafine $\mathrm{TiO}_{2}(<100 \mathrm{~nm})$ is used increasingly in other industrial products, such as toothpastes, sunscreens,

\footnotetext{
* Corresponding author. Health Promotion Department, National Institute of Health, Rua Alexandre Herculano, 321, 4000-055 Porto, Portugal. Tel.: +351 223401185 ; fax: +351223401149.

E-mail addresses: monicabotelho@hotmail.com, monica.botelho@insa.min-saude.pt (M.C. Botelho).
}

cosmetics, pharmaceuticals, and food products [4]. Human exposure may occur during both manufacturing and use. Such widespread use and its potential entry in the body through dermal, ingestion, and inhalation routes suggest that $\mathrm{TiO}_{2}$ nanoparticles pose a potential exposure risk to humans, livestock, and the ecosystem [4-9].

However, it has been difficult to establish a comprehensive mechanism of nanoparticle cytotoxicity based on previous, and rather inconsistent, observations. For instance, some reports indicated that exposure of cells to $\mathrm{TiO}_{2}$ leads to lipid peroxidation, DNA damage, caspase activation followed by micronuclei formation, chromatin condensation and eventual cell death via apoptosis. However, other investigators have reported that $\mathrm{TiO}_{2}$ nanoparticle exposure instead causes plasma membrane damage and decrements in mitochondrial function. There are even reports that $\mathrm{TiO}_{2}$ exposure does not lead to membrane damage, caspase activation or cell death [10].

These conflicting results are likely caused by variations in experimental procedures. Further differences such as protein adsorption prior to cell exposure and particle dispersion/agglomeration have also been recently shown to play important roles. These input variables are likely related to varied toxicological outputs. It is of paramount importance to identify the mechanistic 
response of exposure-prone cells to nanomaterials as they are not only potential environmental exposure hazards, but are continuously employed in biomedical applications in many different tissues and compartments inside the body [10].

We have therefore carried out a comparative study on the cytotoxic effects of common, widely used $\mathrm{TiO}_{2}$ nanoparticles on gastric epithelial cells. Two dispersion media were used for this purpose: one protein rich and the other with one type of protein alone. We evaluated proliferation, apoptosis, oxidative stress and genotoxicity of exposed cells. To the best of our knowledge, this is the first report addressing cytotoxicity of nanomaterials on gastric epithelial cells.

\section{Materials and methods}

\subsection{Nanoparticles}

$\mathrm{TiO}_{2}$ nanoparticles (commercial grade, Aeroxide $\mathrm{TiO}_{2} \mathrm{P}-25$, primary size $21 \mathrm{~nm}, 80 / 20$ anatase/rutile) were obtained from Degussa Corp. (Parsippany, NJ). $\mathrm{TiO}_{2}$ nanopowder 637254 (titanium (IV) oxideanatase, $<25 \mathrm{~nm}$ ) were purchased from SigmaAldrich (St. Louis, MO).

\subsection{Particle preparation and characterization}

$\mathrm{TiO}_{2}$ NPs were suspended in two different dispersion media: Milli-Q water and RPMI supplemented with $10 \%$ FBS or $2 \%$ BSA in phosphate-buffered saline (PBS) and probe sonicated at $30 \mathrm{~W}$ for $5 \mathrm{~min}$ ( $1.5 \mathrm{~min}$ pulse on and $1 \mathrm{~min}$ pulse off for two times and a final pulse of $2 \mathrm{~min})$.

The average hydrodynamic size, size distribution and zeta potential of $\mathrm{TiO}_{2} \mathrm{NPs}$ in water were determined by dynamic light scattering (DLS) and phase analysis light scattering respectively using a Zetasizer Nano-ZS equipped with $4.0 \mathrm{~mW}, 633 \mathrm{~nm}$ laser (Model ZEN3600, Malvern Instruments Ltd., Malvern, UK).

Before use, $\mathrm{TiO}_{2}$ NPs stock suspension $(150 \mu \mathrm{g} / \mathrm{mL})$ in medium was serially diluted to desired concentrations in fresh suspension medium. All samples were prepared under sterile conditions.

\subsection{Particle treatment}

The treatment experimental design consisted of serial concentrations of $\mathrm{TiO}_{2}$ NPs suspended in two different media: RPMI supplemented with $10 \%$ FBS or $2 \%$ BSA in phosphate-buffered saline (PBS), applied to cells from a single passage to minimize confounding of comparisons by passage-to-passage variation of the cultured cells. Each multiwell cell culture plate included negative controls.

\subsection{Cell line and cell culture}

AGS (gastric epithelial cancer) cells were cultured and maintained at $37{ }^{\circ} \mathrm{C}$ in a $5 \% \mathrm{CO}_{2}$ humidified atmosphere in RPMI medium (Sigma) with 10\% FBS (Sigma) and 1\% penicillin/ streptomycin (Sigma). Cells were passaged every 5 days. Before treatments with nanoparticles suspended in BSA, cells were allowed to reach $80 \%$ confluence before serum-starved for $16 \mathrm{~h}$.

\subsection{Trypan blue exclusion assay}

The trypan blue exclusion method was used to assess cell viability. AGS cells were plated and incubated until $80 \%$ confluency. The cells were treated with $\mathrm{TiO}_{2}$-nanoparticles. After treatment, the cells were harvested by trypsinization and counted under microscope after trypan blue staining. Three independent experiments were carried out based on the following formula: cell viability percentage $=$ number of cells in drug treatment group/ number of cells in control group $\times 100 \%$.

\subsection{Proliferation assay}

The CellTiter 96 AQ nonradioactive cell-proliferation assay (Promega) was used to assess cell viability. The assay is composed of the tetrazolium compound MTS and an electron coupling reagent, PMS. MTS is reduced by viable cells to formazan, which can be measured with a spectrophotometer by the amount of $490 \mathrm{~nm}$ absorbance. Formazan production is time-dependent and proportional to the number of viable cells. AGS cells were cultured in $0.1 \mathrm{~mL}$ RPMI media in 96-well flat-bottomed plates. Cultures were seeded at $1 \times 10^{4}$ cells/well and allowed to attach overnight. After the indicated time of incubation with the appropriate medium, $20 \mu \mathrm{L}$ reagent was added per well, and cells were incubated $1 \mathrm{~h}$ before measuring absorbance at $490 \mathrm{~nm}$. Background absorbance from the control wells was subtracted. Studies were performed in triplicate for each experimental condition.

\subsection{Apoptosis}

Apoptosis in cell cultures was assessed with the in situ cell death detection kit, fluorescein (TUNEL technology) (Roche), analyzed by fluorescence microscopy. TUNEL assay (Terminal deoxynucleotidyl transferase-mediated deoxyuridine triphosphate nick endlabeling) was performed according to the manufacturer's instructions. Nuclei were counter-stained with DAPI (Roche Diagnostics, Basel, Switzerland). The percentage of TUNEL-stained nuclei was evaluated in relation to every DAPIstained nuclei observed. Immunofluorescence was visualized under a fluorescence microscope (Olympus, BH-2, UK). The percentage of stained cells was evaluated by counting the cells stained with TUNEL divided by the total number of nuclei stained with DAPI at a magnification $200 \times$ field. One thousand nuclei were evaluated. Three independent experiments were performed.

\subsection{Oxidative stress assay}

Oxidative stress was analysed by evaluation of GSHt, GSH and GSSG levels The intracellular levels of GSH and GSSG in $\mathrm{TiO}_{2}-$ nanoparticle-treated AGS cells were evaluated by the DTNB-GSSG reductase recycling assay, as previously described [11]. After a 3-h treatment with $150 \mu \mathrm{g} / \mathrm{mL} \mathrm{TiO}_{2}$ nanoparticles, the treated cells were lysed and proteins were precipitated with $5 \% \mathrm{HClO}_{4}$. After centrifugation $\left(16,000 \mathrm{~g}, 10 \mathrm{~min}, 48^{\circ} \mathrm{C}\right)$, the supernatant obtained was used for the determination of GSHt, GSH and GSSG by spectrophotometry at $412 \mathrm{~nm}$.

\subsection{Comet assay}

After treatment, cells were washed twice with prechilled PBS $\left(\mathrm{Mg}^{2+}\right.$ and $\mathrm{Ca}^{2+}$-free), centrifuged at $78 \times \mathrm{g}$ for $5 \mathrm{~min}$ and resuspended in PBS. Cell viability was over $85 \%$ for the tested dose in this study as assessed using trypan blue dye-exclusion staining. The alkaline version of the comet assay was performed as described by [12] with minor modifications. Briefly, cells collected by centrifugation ( $9000 \mathrm{rpm}$ for $3 \mathrm{~min}$ ) and suspended in $60 \mu \mathrm{L}$ of $0.6 \%$ low-melting-point agarose (LMA) in PBS ( $\mathrm{pH} 7.4)$ were dropped onto a frosted slide precoated with a layer of $1 \%$ normal melting point agarose. Slides were placed on ice for $4 \mathrm{~min}$ and allowed to solidify. Coverslips were then removed and slides were immersed in freshly prepared lysing solution $(2.5 \mathrm{M} \mathrm{NaCl}$, $100 \mathrm{mM} \mathrm{Na}{ }_{2}$ EDTA, $10 \mathrm{mM}$ TrisBase, 0.25MNaOH, pH 10) for $1 \mathrm{~h}$ at $4{ }^{\circ} \mathrm{C}$, in the dark. After lysis, slides were placed on a horizontal 
electrophoresis tank in an ice bath. The tank was filled with freshly made alkaline electrophoresis solution ( $1 \mathrm{mM} \mathrm{Na} \mathrm{N}_{2}$ EDTA, $300 \mathrm{mM} \mathrm{NaOH}, \mathrm{pH} 13$ ) to cover the slides, and they were left for 20 min in the dark to allow DNA unwinding and alkali-labile site expression.

Electrophoresis was carried out for $20 \mathrm{~min}$ at $30 \mathrm{~V}$ and $300 \mathrm{~mA}$ $(1.2 \mathrm{~V} / \mathrm{cm})$. The slides were then washed for $10 \mathrm{~min}$ with $1 \mathrm{~mL}$ of neutralizing solution (0.4 M TrisBase, $\mathrm{pH}$ 7.5). After neutralization, gels were stained with $100 \mu \mathrm{L}$ of ethidium bromide solution $(20 \mu \mathrm{g} / \mathrm{mL})$ and covered with coverslips for $20 \mathrm{~min}$. After staining, the slides were washed twice with ice-cold bidistilled water for 20 min.

Slides were coded and examined by a 'blind' scorer using a magnification of $400 \times$. One hundred randomly selected cells (50 per replicate) were examined for each dose. Image capture and analysis were performed with Comet Assay IV software (Perceptive Instruments); percentage of tail DNA (\%T) was the DNA damage parameter evaluated according to what has been recommended by Kumaravel et al. [13]. The percentage DNA in the tail is the fraction of DNA in the tail divided by the amount of DNA in the cell multiplied by 100 .

\subsection{Statistical analysis}

Data were expressed as mean $\pm \mathrm{SD}$. $t$-test was used to assess the statistical significance of differences. $P<0.05$ was considered statistically significant.

\section{Results}

\subsection{Nanoparticles characterization}

The mean hydrodynamic diameter of Sigma $\mathrm{TiO}_{2} \mathrm{NPs}$ in Milli Q water as measured by DLS was $420.7 \mathrm{~nm}$ and the zeta potential was $-9.96 \mathrm{mV}$. Results of size and zeta potential of Degussa $\mathrm{TiO}_{2}$ NPs were respectively, $160.5 \mathrm{~nm}$ and $-27.8 \mathrm{mV}$.

\subsection{FBS impairs the effects of $\mathrm{TiO}_{2}$ nanoparticles on cell proliferation}

Generally, serum is added to the cell culture medium such as RPMI because the serum component is important for normal cell growth. Therefore, we used RPMI supplemented with FBS for nanoparticles suspension. The growth levels show that no effect is observed by this treatment with increasing concentrations of $\mathrm{TiO}_{2}-$ nanoparticles (Fig. 1A and B).

\section{3. $\mathrm{TiO}_{2}$ nanoparticles increased the proliferation of epithelial cells in vitro}

We used a simple "FBS mimic" protein cocktail containing similar concentrations of BSA and PBS for nanoparticle suspension [14]. To begin investigating the effect of $\mathrm{TiO}_{2}$ nanoparticles on cell viability and proliferation, AGS cells were seeded on 96well plates, starved overnight, treated with increasing concentrations of $\mathrm{TiO}_{2}$ nanoparticles for $3 \mathrm{~h}, 6 \mathrm{~h}$ and $24 \mathrm{~h}$, cultivated for 24 hours and then analyzed by MTS assay (Fig. 2A and B). The growth levels show that treated cells proliferated significantly faster and more than control cells. We confirmed the increase in cell viability using the concentration of $150 \mu \mathrm{g} / \mathrm{mL}$ of $\mathrm{TiO}_{2}$ nanoparticles for $3 \mathrm{~h}$. This concentration and time were confirmed by trypan blue assay and used for the subsequent assays. Our results suggest that the increase of both proliferation and overall survival in AGS cells is a consequence of nanoparticle treatment. The experiments were done in triplicate $(P<0.01)$.
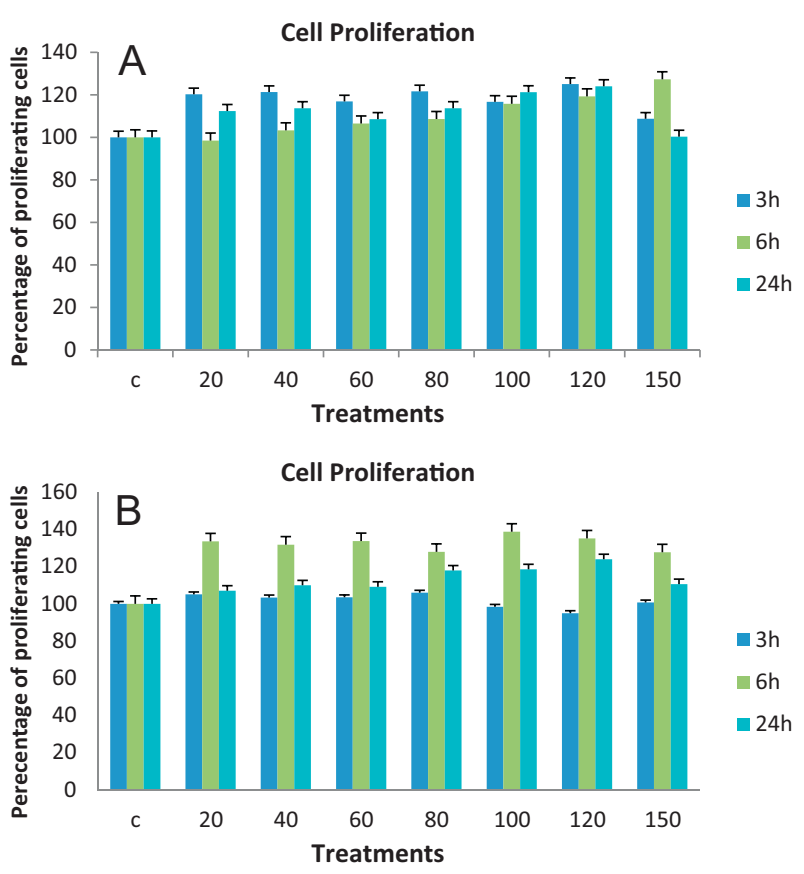

Fig. 1. Cell proliferation assay of $\mathrm{AGS}$ cells treated with $\mathrm{TiO}_{2}$ nanoparticles suspension in RPMI supplemented with FBS. The growth levels show no differences between control and treated AGS cells. A. AGS cells were seeded on 96-well plates, starved o. n., treated with increasing concentrations of $\mathrm{TiO}_{2}$ nanoparticles (Sigma) suspension, for 3, 6 and $24 \mathrm{~h}$. B. AGS cells were seeded on 96-well plates, starved o. n., treated with increasing concentrations of $\mathrm{TiO}_{2}$ nanoparticles (Degussa) suspension, for 3, 6 and $24 \mathrm{~h}$.

3.4. $\mathrm{TiO}_{2}$ nanoparticles decreased the apoptosis of gastric epithelial cells in vitro

To analyze apoptosis, AGS cells were seeded on 96-well plates, starved o. n., treated with $150 \mu \mathrm{g} / \mathrm{mL}$ of $\mathrm{TiO}_{2}$ nanoparticles (Sigma)
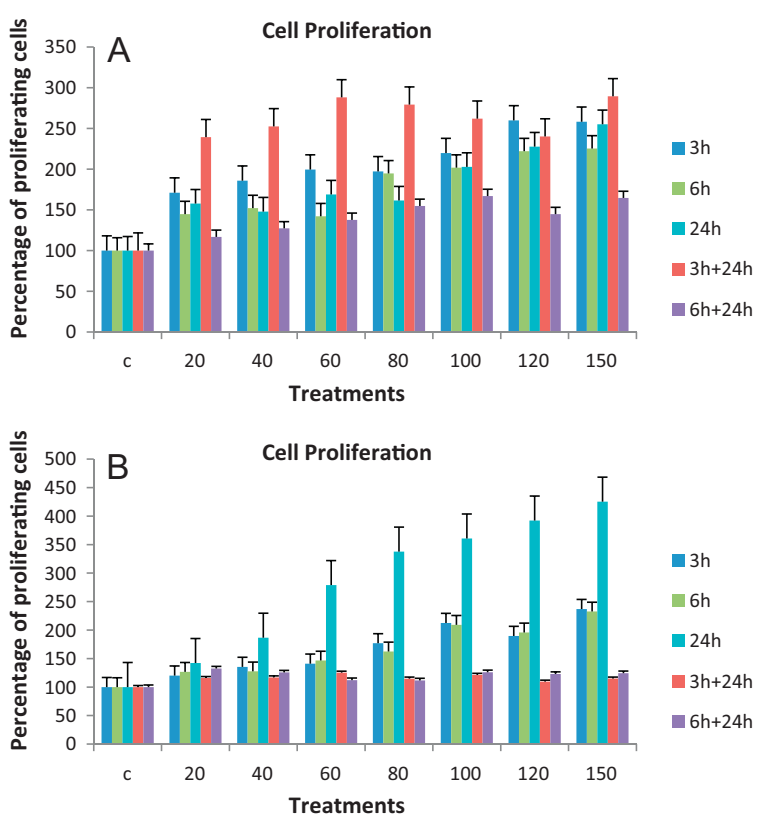

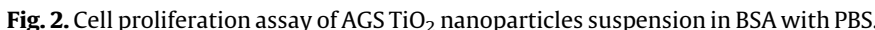
The growth levels show that treated cells proliferated significantly faster and more than control cells $(P<0.01$; control vs. $150 \mu \mathrm{g} / \mathrm{mL})$. A. AGS cells were seeded on 96well plates, starved o. n., treated with increasing concentrations of $\mathrm{TiO}_{2}$ nanoparticles (Sigma) suspension, for 3, 6 and $24 \mathrm{~h}$, cultivated for $24 \mathrm{~h}$ and then analyzed by MTS assay. B. AGS cells were seeded on 96-well plates, starved o. n., treated with increasing concentrations of $\mathrm{TiO}_{2}$ nanoparticles (Degussa) suspension, for 3, 6 and $24 \mathrm{~h}$, cultivated for $24 \mathrm{~h}$ and then analyzed by MTS assay. 


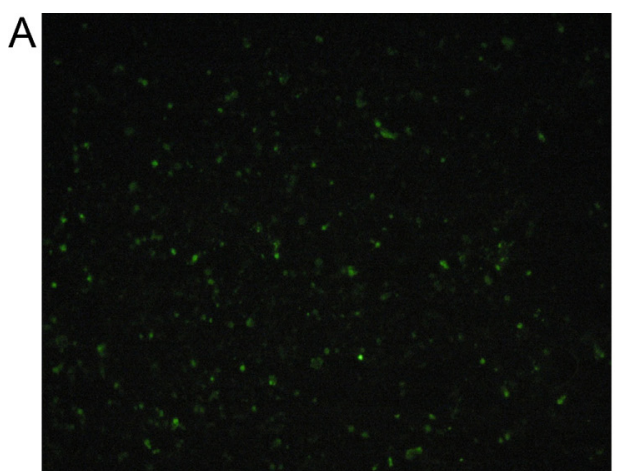

Control

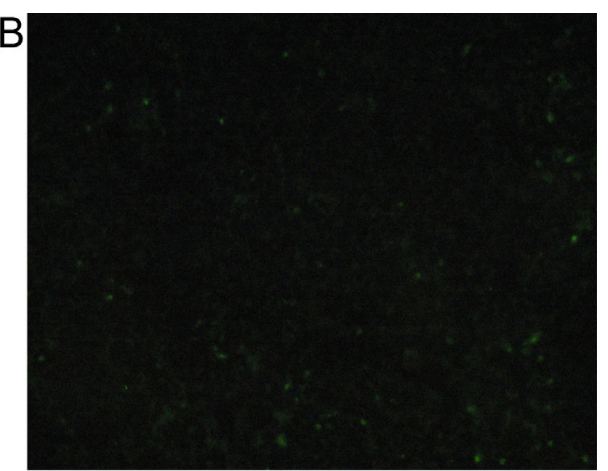

$\mathrm{TiO}_{2}$

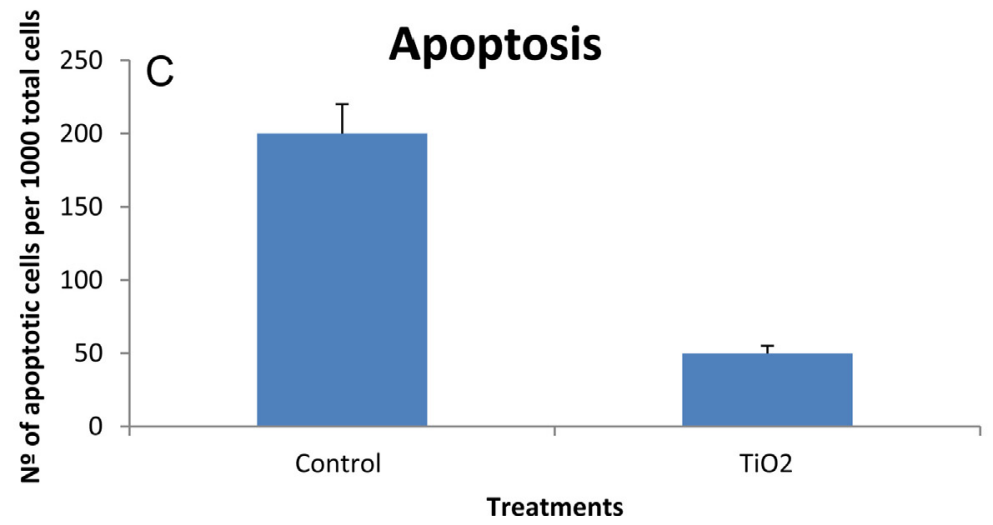

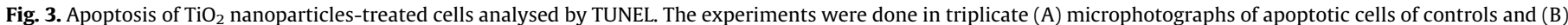

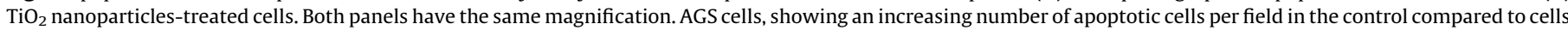

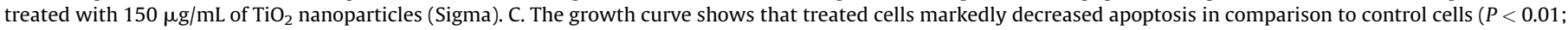
control vs. $150 \mu \mathrm{g} / \mathrm{mL}$ )

for $3 \mathrm{~h}$ and then analyzed by TUNEL assay. Apoptotic levels show that treated cells markedly decreased apoptosis in comparison to control cells. The experiments were done in triplicate $(P<0.01)$. AGS cells showed an increasing number of apoptotic cells per field in the control (Fig. 3A) compared to cells treated with $150 \mu \mathrm{g} / \mathrm{mL}$ of $\mathrm{TiO}_{2}$ nanoparticles (Fig. 3B). Cell counts show that treated cells markedly decreased apoptosis in comparison to control cells (Fig. 3C).

3.5. $\mathrm{TiO}_{2}$ nanoparticles increased oxidative stress of gastric epithelial cells in vitro

Oxidative stress was determined by measuring oxidized glutathione (GSSG). AGS cells show an increase in GSSG levels in the cells treated with $150 \mu \mathrm{g} / \mathrm{mL}$ of $\mathrm{TiO}_{2}$ nanoparticles compared

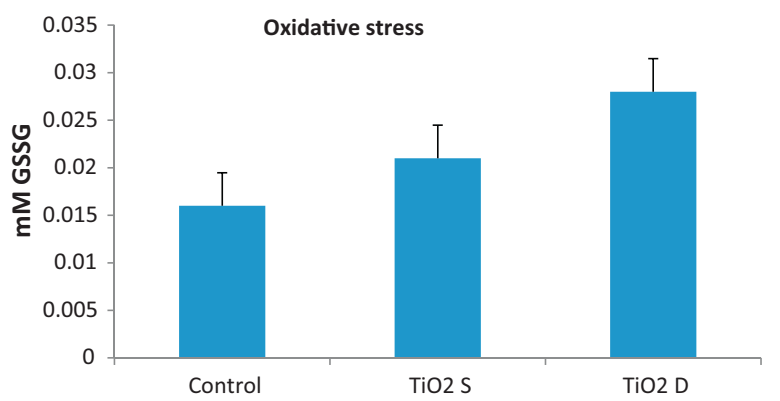

Fig. 4. Oxidative stress was determined by measuring oxidized glutathione (GSSG). AGS cells show an increase in GSSG levels in treated cells with $150 \mu \mathrm{g} / \mathrm{mL}$ of $\mathrm{TiO}_{2}$ nanoparticles compared to control cells. A significant difference can be observed in GSSG levels when compared with control group $(P<0.05$; control vs. $150 \mu \mathrm{g} / \mathrm{mL})$. to controls. In Fig. 4, the levels of GSSG in AGS cells after a 3-h incubation period with $\mathrm{TiO}_{2}$ nanoparticles and in control cells can be observed. A significant difference can be observed in GSSG levels when compared with control group, as shown in Fig. 4. These results show that $\mathrm{TiO}_{2}$ nanoparticles treatment with was able to elicit the alterations in glutathione status observed.

\subsection{Induced genotoxicity of gastric epithelial cells in vitro by $\mathrm{TiO}_{2}$ nanoparticles}

Genotoxicity was detected by Comet assay. AGS cells show an increase in tail intensity in $150 \mu \mathrm{g} / \mathrm{mL}$ of $\mathrm{TiO}_{2}$ nanoparticles (Sigma)-treated cells compared to control. AGS cells show less damaged nuclei in the control compared to cells treated with $150 \mu \mathrm{g} / \mathrm{mL}$ of $\mathrm{TiO}_{2}$ nanoparticles (Fig. 5A and B). In the comet assay, there was a 1.88 -fold significant $(P<0.05)$ increase in \%Tail DNA when the cells were treated with $\mathrm{TiO}_{2}$ nanoparticles at a dose of $150 \mu \mathrm{g} / \mathrm{mL}$ for $3 \mathrm{~h}$ exposure, i.e. $47.34 \pm 9 \%$ for treated cells versus $25.19 \pm 5 \%$ for untreated cells (Fig. 5 C).

\section{Discussion}

The purpose of this study was to examine gastric epithelial cell responses to $\mathrm{TiO}_{2}$ nanoparticles. To our knowledge, this is the first study addressing these effects in a gastric epithelial cell line. Nanoparticles were evaluated over a range of concentrations. In the present study, we characterized the effect of $\mathrm{TiO}_{2}$ nanoparticles in human gastric cells using cell biological approaches normally used in carcinogenesis studies, like proliferation, apoptosis, oxidative stress and genotoxicity. 


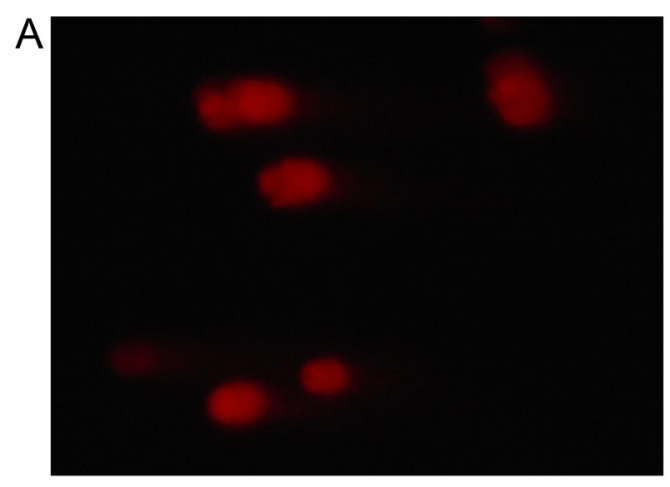

Control

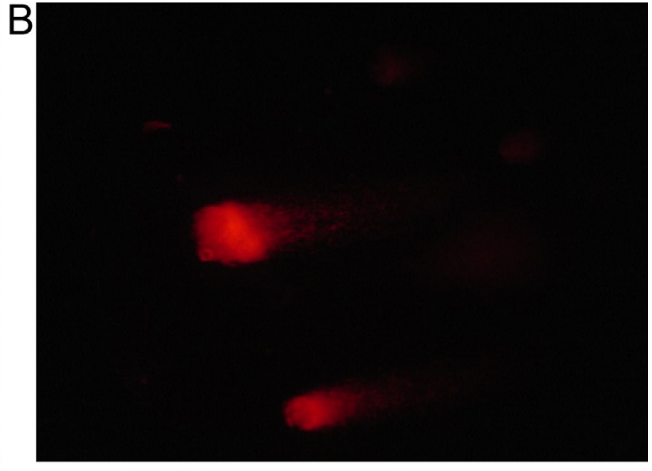

$\mathrm{TiO}_{2}$

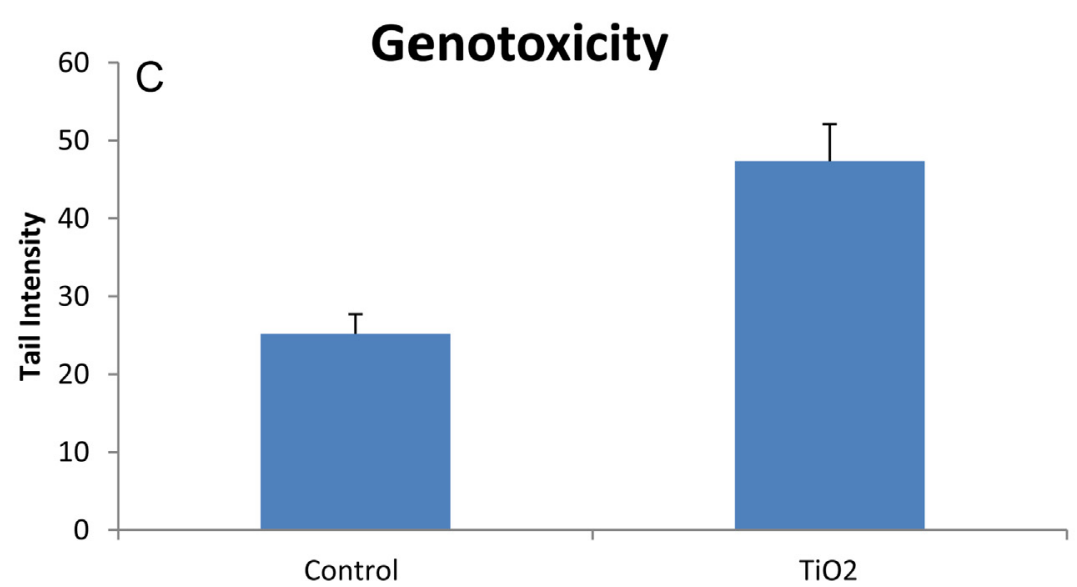

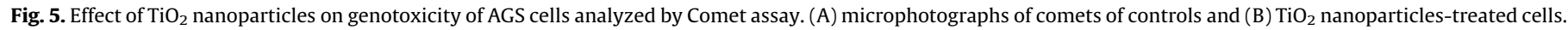

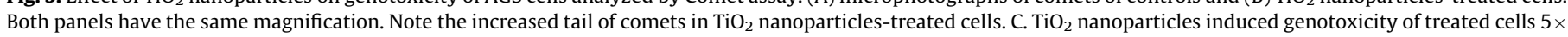
fold than control cells $\left(P<0.01\right.$; control vs. $\mathrm{TiO}_{2}$ nanoparticles-treated cells).

First, we used RPMI supplemented with FBS for the suspension of $\mathrm{TiO}_{2}$ nanoparticles. This treatment caused no alteration on cell proliferation. These results are explained by the effect of the protein adsorption ability of metal oxide nanoparticles on the cytotoxicity. First, the adsorption of the components of the culture media onto the metal oxide nanoparticles induces a starvation state and subsequent enervation of cells in vitro. Therefore, a correct toxicity assessment may be impaired by this adsorption effect. Second, the coating of the metal oxide nanoparticles with proteins may change their biological activities. Generally, the prepared cell culture media contain proteins from the supplemented FBS. The adsorption of medium components by ultrafine metal oxide particles, especially protein adsorption, affects the cell growth and metabolism; therefore, the adsorption ability affects an accurate cytotoxicity assessment [14].

In this investigation, $\mathrm{TiO}_{2}$ nanoparticles were selected as a model nanoparticle and bovine serum albumin (BSA) was selected as a model protein for studying the effect of $\mathrm{TiO}_{2}$ nanoparticle in a gastric epithelial cell line. Fetal bovine serum (FBS) is an effective dispersing agent for $\mathrm{TiO}_{2}$ nanoparticles due to synergistic effects of its multiple protein components [14]. Ji et al. [14] successfully reproduced FBS using a simple "FBS mimic" protein cocktail containing similar concentrations of BSA and PBS that we included in the present study [14]. With this nanoparticle suspension we observed increased proliferation of gastric epithelial cells. We have no references so far in the literature to compare our results concerning nanoparticles and gastric epithelial cell proliferation. Nevertheless, Knaapen et al. [15] found that $\mathrm{TiO}_{2}$-nano drive deregulated cell proliferation and anchorage-independent growth in lung epithelial cells [15].
Apoptotic cell loss in carcinogenesis has been examined by TUNEL method [16]. We used this method to analyze apoptosis in the present work and found it dramatically decreased in the cells after treatment with $\mathrm{TiO}_{2}$ nanoparticles. In agreement, alterations in the balance between cell proliferation and apoptosis may reflect an important mechanism of carcinogenesis [17]. Our findings are further supported by microarray gene expression profiles indicating roles of $\mathrm{TiO}_{2}$ nanoparticles in modulating numerous gene expressions involved in cell cycle and apoptosis [18], indicating that $\mathrm{TiO}_{2}$ nanoparticles can modulate intracellular physiological processes.

One of the most discussed mechanisms behind the health effects induced by ambient particles is the ability of particles to cause oxidative stress. This mechanism is believed to be important for the toxicity of manufactured nanoparticles as well. In vitro studies have generally supported the pathophysiological responses found in animal models, including increased generation of ROS in cells exposed to various nanomaterials. Many in vitro studies have identified increased ROS generation as an initiating factor of toxicity in nanoparticle exposed cells. The interactions of particles with cell membranes result in the generation of reactive oxygen species (ROS), and the generated oxidative stress may cause a breakdown of membrane lipids, an imbalance of intracellular calcium homeostasis, and DNA breakage [19-21]. In the present study, we found increased oxidative stress in $\mathrm{TiO}_{2}$-nanoparticlestreated cells. In accordance, previous studies have shown that nano- $\mathrm{TiO}_{2}$ induces oxidative stress-mediated toxicity in many cell types $[22-24]$ and that nano- $\mathrm{TiO}_{2}$ exposure induces ROS to cause DNA lesions $[4,23,25,26]$.

The DNA damage response is triggered by the detection of DNA lesions. This response consists of an orderly sequence of signal 
transduction events that can induce the accumulation of genetic errors, that play a critical role in responding to various stresses that cause DNA damage, especially ROS [27]. We confirmed the genotoxic effects of nano- $\mathrm{TiO}_{2}$ on gastric epithelial cells using alkaline single-cell gel electrophoresis (Comet). Kang et al. [28] found the same effects on lymphocytes.

Studying the genotoxic molecular mechanism of $\mathrm{TiO}_{2}$ nanoparticles has helped elucidate pathways related to its tumourigenesis. The central hypothesis based on our studies is that genotoxic events and sustained signaling pathway stimulation drive deregulated cell proliferation and anchorage-independent growth, the processes both required for mutations and progression towards neoplastic lesions play a role in $\mathrm{TiO}_{2}$ nanoparticlesinduced mutagenesis and carcinogenicity. The well-known biological mechanisms, such as the alteration of cell-signaling pathways and induction of DNA damage, play a vital role in neoplasia induction. The initiation stage of carcinogenesis is mainly characterized by genotoxic processes, which may lead to irreversible changes in the structure of cellular genetic materials. Although DNA repair pathways exist for DNA restoration, however, erroneous repair and extensive DNA damage may cause mutations and ultimately lead to cell transformation [29]. Furthermore, since there is a link between DNA damage, mutations, and cancer, particles that are potent in causing DNA damage can be regarded as more likely to have an effect on cancer development. In agreement, Knaapen et al. [15] suggested that ROS generation induced by $\mathrm{TiO}_{2}$ nanoparticles might directly or indirectly damage DNA to cause genotoxicity and impact on cellular signaling pathways to modulate cell proliferation, resulting irreversible cell transformation [15]. In addition, the International Agency for Research on Cancer (IARC) recently classified $\mathrm{TiO}_{2}$ as a Group 2B carcinogen (possibly carcinogenic to humans) based on mechanistic and animal studies [30].

Taken together, the effects observed in $\mathrm{TiO}_{2}$-nanoparticlestreated cells seem to be interconnected. Although we do not yet fully understand the physiological functions of nanoparticles, the present study revealed novel aspects in gastric epithelial, on the potential routes of exposure to nanoparticles. Through its effects in cell biology, $\mathrm{TiO}_{2}$ nanoparticles are likely to participate in a number of carcinogenesis-mediated processes, such as increased cell proliferation, decreased apoptosis, increased oxidative stress and increased genotoxicity, all of which are processes needed for cancer cell survival. The effects of nanoparticles on the cell cycle may contribute to the high proliferation rate and accumulation of genetic changes. Oxidative stress may be the reason for the uncontrolled proliferation seen in $\mathrm{TiO}_{2}$ nanoparticles-treated cells and could be involved in cancer-associated pathways. Additional work needs to be undertaken to understand the mechanisms of damage.

\section{Disclosure of interest}

The authors declare that they have no conflicts of interest concerning this article.

\section{Acknowledgements}

We would like to show our deepest appreciation to Pr. Victor Costa for the collaboration and valuable insight on oxidative stress. We would also like to acknowledge NanoLINEN network project funding for this work.

\section{References}

[1] Brumfiel G. Consumer products leap aboard the nano bandwagon. Nature 2006;440:262
[2] Griffitt RJ, Weil R, Hyndman KA, Denslow ND, Powers K, Taylor D, Barber DS. Exposure to copper nanoparticles causes gill injury and acute lethality in zebrafish (Danio rerio). Environ Sci Technol 2007;41:8178-86.

[3] Hu X, Cook S, Wang P, Hwang HM. In vitro evaluation of cytotoxicity of engineered metal oxide nanoparticles. Sci Total Environ 2009;407:3070-2.

[4] Wang JJ, Sanderson BJ, Wang H. Cyto- and genotoxicity of ultrafine $\mathrm{TiO}_{2}$ particles in cultured human lymphoblastoid cells. Mutat Res 2007;628:99106.

[5] Oberdörster G, Maynard A, Donaldson K, Castranova V, Fitzpatrick J, Ausman K, Carter J, Karn B, Kreyling W, Lai D, Olin S, Monteiro-Riviere N, Warheit D, Yang H. Principles for characterizing the potential human health effects from exposure to nanomaterials: elements of a screening strategy. Part Fibre Toxicol 2005;2:8.

[6] Long MS, Keating CD. Nanoparticle conjugation increases protein partitioning in aqueous two-phase systems. Anal Chem 2006;78:379-86.

[7] Jin CY, Zhu BS, Wang XF, Lu QH. Cytotoxicity of titanium dioxide nanoparticles in mouse fibroblast cells. Chem Res Toxicol 2008;21:1871-7.

[8] Zhao J, Bowman L, Zhang X, Vallyathan V, Young SH, Castranova V, Ding M. Titanium dioxide $\left(\mathrm{TiO}_{2}\right)$ nanoparticles induce JB6 cell apoptosis through activation of the caspase-8/Bid and mitochondrial pathways. J Toxicol Environ Health A 2009; $72: 1141-9$.

[9] Liu S, Xu L, Zhang T, Ren G, Yang Z. Oxidative stress and apoptosis induced by nanosized titanium dioxide in PC12 cells. Toxicology 2010;267:172-7.

[10] Sohaebuddin SK, Thevenot PT, Baker D, Eaton JW, Tang L. Nanomaterial cytotoxicity is composition, size, and cell type dependent. Part Fibre Toxicol 2010;7:22.

[11] Costa V, Quintanilha A, Moradas-Ferreira P. Protein oxidation, repair mechanisms and proteolysis in Saccharomyces cerevisiae. IUBMB Life 2007;59:2938.

[12] Singh NP, McCoy MT, Tice RR, Schneider EL. A simple technique for quantification of low levels of DNA damage in individual cells. Exp Cell Res 1988;175:184-91.

[13] Kumaravel T, Vilhar B, Faux SP, Jha AN. Comet Assay measurements: a perspective. Cell Biol Toxicol 2009;25:53-64.

[14] Ji Z, Jin X, George S, Xia T, Meng H, Wang X, Suarez E, Zhang H, Hoek EM, Godwin $\mathrm{H}$, Nel AE, Zink JI. Dispersion and stability optimization of $\mathrm{TiO}_{2}$ nanoparticles in cell culture media. Environ Sci Technol 2010:44:7309-14.

[15] Knaapen AM, Borm PJ, Albrecht C, Schins RP. Inhaled particles and lung cancer. Part A: mechanisms. Int J Cancer 2004;109:799-809.

[16] Takaba K, Saeki K, Suzuki K, Wanibuchi H, Fukushima S. Significant overexpression of metallothionein and cyclin D1 and apoptosis in the early process of rat urinary bladder carcinogenesis induced by treatment with N-butyl-N(4-hydroxybutyl)nitrosamine or sodium L-ascorbate. Carcinogenesis 2000:21:691-700.

[17] Otori K, Yano Y, Takada N, Lee CC, Hayashi S, Otani S, Fukushima S. Reversibility and apoptosis in rat urinary bladder papillomatosis induced by uracil. Carcinogenesis 1997;18:1485-9.

[18] Chen HW, Su SF, Chien CT, Lin WH, Yu SL, Chou CC, Chen JJ, Yang PC. Titanium dioxide nanoparticles induce emphysema-like lung injury in mice. FASEB J 2006;20:2393-5.

[19] Petruska JM, Leslie KO, Mossman BT. Enhanced lipid peroxidation in lung lavage of rats after inhalation of asbestos. Free Radic Biol Med 1991;11:42532.

[20] Clutton S. The importance of oxidative stress in apoptosis. Br Med Bull 1997:53:662-8

[21] Shukla RK, Kumar A, Pandey AK, Singh SS, Dhawan A. Titanium dioxide nanoparticles induce oxidative stress-mediated apoptosis in human keratinocyte cells. J Biomed Nanotechnol 2011;7:100-1.

[22] Ramires PA, Romito A, Cosentino F, Milella E. The influence of titania/hydroxyapatite composite coatings on in vitro osteoblasts behaviour. Biomaterials 2001;22:1467-74.

[23] Gurr JR, Wang AS, Chen CH, Jan KY. Ultrafine titanium dioxide particles in the absence of photoactivation can induce oxidative damage to human bronchial epithelial cells. Toxicology 2005;213:66-73.

[24] Hussain SM, Hess KL, Gearhart JM, Geiss KT, Schlager JJ. In vitro toxicity of nanoparticles in BRL 3A rat liver cells. Toxicol In Vitro 2005;19:975-83.

[25] Dunford R, Salinaro A, Cai L, Serpone N, Horikoshi S, Hidaka H, Knowland J. Chemical oxidation and DNA damage catalysed by inorganic sunscreen ingredients. FEBS Lett 1997:418:87-90.

[26] Rahman Q, Lohani M, Dopp E, Pemsel H, Jonas L, Weiss DG, Schiffmann D. Evidence that ultrafine titanium dioxide induces micronuclei and apoptosis in Syrian hamster embryo fibroblasts. Environ Health Perspect 2002;110:797800.

[27] Matés JM, Sánchez-Jiménez FM. Role of reactive oxygen species in apoptosis implications for cancer therapy. Int J Biochem Cell Biol 2000;32:157-70.

[28] Kang SJ, Kim BM, Lee YJ, Chung HW. Titanium dioxide nanoparticles trigger p53-mediated damage response in peripheral blood lymphocytes. Environ Mol Mutagen 2008;49:399-405.

[29] Huang S, Chueh PJ, Lin YW, Shih TS, Chuang SM. Disturbed mitotic progression and genome segregation are involved in cell transformation mediated by nano- $\mathrm{TiO}_{2}$ long-term exposure. Toxicol Appl Pharmacol 2009;241:182-94.

[30] IARC monographs on the evaluation of carcinogenic risks to humans: carbon black, titanium dioxide, and talc. 2010; p. 93. 